\title{
Heavy Metal Content and Health Risk Assessment of Urban Road Dust from the Historical Center of Havana, Cuba
}

Oscar Diaz Rizo ( $\sim$ odrizo@instec.cu )

Instituto Superior de Tecnologias y Ciencias Aplicadas https://orcid.org/0000-0002-5705-163X Amaya Casanova Díaz

INSTEC: Instituto Superior de Tecnologias y Ciencias Aplicadas

Arianna Torres Ramos

INSTEC: Instituto Superior de Tecnologias y Ciencias Aplicadas

Dayron Ramos López

INSTEC: Instituto Superior de Tecnologias y Ciencias Aplicadas

\section{Research Article}

Keywords: Heavy metals, XRF, urban road dust, pollution, enrichment factor, health assessment

Posted Date: April 5th, 2021

DOI: https://doi.org/10.21203/rs.3.rs-333351/v1

License: (a) (i) This work is licensed under a Creative Commons Attribution 4.0 International License.

Read Full License 


\title{
Heavy metal content and health risk assessment of urban road dust from the historical center of Havana, Cuba \\ Oscar DÍAZ RIZO, Amaya O. CASANOVA DÍAZ, Arianna G. TORRES RAMOS, Dayron RAMOS LÓPEZ Instituto Superior de Tecnologías y Ciencias Aplicadas (InSTEC), Universidad de La Habana. Ave. Salvador Allende No. 1110, Quinta de los Molinos, La Habana 10400, Cuba. odrizo@instec.cu, ocasanova@instec.cu
}

\begin{abstract}
Street road dust samples were collected at 33 stations of the Historical center of Old Havana. Samples were analyzed for the determination of some $(\mathrm{Co}, \mathrm{Ni}, \mathrm{Cu}, \mathrm{Zn}$ and $\mathrm{Pb}$ ) heavy metal concentrations using an $\mathrm{X}$-ray fluorescence (XRF) instrument. The mean concentrations of the elements are $\mathrm{Zn}(548.7 \mathrm{mg} / \mathrm{kg}), \mathrm{Pb}(60.8$ $\mathrm{mg} / \mathrm{kg})$, Co $(7.0 \mathrm{mg} / \mathrm{kg}) \mathrm{Ni}(60.6 \mathrm{mg} / \mathrm{kg})$ and $\mathrm{Cu}(73.6 \mathrm{mg} / \mathrm{kg})$ were $\mathrm{Zn}$ and $\mathrm{Pb}$ showed higher values of the background. The study of the Enrichment Factor $(E F)$, the Pollution Index $(I P)$ and the Integral Pollution Index (IPI), showed some stations with high values of contamination close to construction places. Zn was identified as the major pollutant fallowed by the Pb. Nevertheless, the Hazard Index $(H I)$ and Carcinogenic Risks (CR) values do not show risk of getting non-carcinogenic or carcinogenic diseases associated to the analyzed pollutants.
\end{abstract}

Keywords

Heavy metals, XRF, urban road dust, pollution, enrichment factor, health assessment

Ethics approval and consent to participate

Not Applicable

Consent for publication

Not applicable

Availability of data and materials

The datasets used and/or analyzed during the current study are available from the corresponding author on reasonable request.

Competing interests

The authors declare that they have no competing interests

Funding

This study was financially supported by Havana University

Authors' contributions

All authors read and approved the final manuscript. The authors contributed to the present work as follow:

ODR (Leader, Data Analysis, Writting manuscript)

AOCD (Data Analysis, Writting manuscript)

AGTR (Data Collection, Data Analysis)

DRL (Data Collection, Data Analysis) 


\section{Introduction}

Cities are the centers with the greatest amount of anthropogenic activities. Due to rapid urbanization and industrialization, about half of the world population now lives in cities, where the population density, the automotive traffic, industry and economic activities, cause large amounts of pollutants that are discharged into the urban environment. So a lot of environmental problems are arising from air, soil and water pollution. Heavy metal contamination is a major problem, especially in urban atmospheric particles, soil and dust (Lu et al. 2014). The main pollutants associated with urbanized areas are: Copper $(\mathrm{Cu})$, Lead $(\mathrm{Pb})$ and $\mathrm{Zinc}(\mathrm{Zn})$ (Rissler et al. 2012), together with these can be found: Nickel (Ni), Cadmium (Cd) and Chromium (Cr), which appear as a product of industrial activities (Garcia et al. 2014), vehicle emissions, particularly near areas with high traffic (Ordóñez et al. 2015, Charlesworth et al. 2011), construction and restoration processes as well as natural geochemical processes.

Heavy metals in street dust can have a direct influence in public health because they can easily enter the human body by ingestion, skin contact, or breathing. (Maltby et al. 1995; Sutherland and Tolosa, 2000; Wei and Yang, 2010). Some of these metals, like $\mathrm{Pb}, \mathrm{Co}, \mathrm{Cd}, \mathrm{Cu}$ and $\mathrm{Cr}$ are considered dangerous pollutants that accumulate in the human body with a relatively high half-life (Salt et al. 1995). Furthermore, some types of Cadmium, Chromium and Copper may be associated with health effects from dermatitis to various types of cancer (Das et al. 1997; Onder and Dursun, 2006). Consequently, the geochemical characterization of soil and dust contamination is an important contribution to the characterization of the urban environment and the potential risks associated with health.

The Historical Center of Havana city $(\mathrm{HCH})$, capital of Cuba, is characterized by the wide development of the restoration activities of its dissimilar historical sites, monuments and tourist facilities, including some demolitions, especially before the $500^{\text {th }}$ anniversary of the city in 2019 . The last implies the use of large amounts of construction materials and machinery representing important sources of heavy metal emissions. Furthermore, the $\mathrm{HCH}$ is surrounded by high traffic avenues. In this sense, the goal of the present study was to determine the heavy metal content in urban dust in order to evaluate its impact to the $\mathrm{HCH}$ environmental pollution as well as health risk impact to the local population.

\section{Methods and Materials}

The HCH is nearly the $50 \%$ of the Old Havana municipality area although the $66.1 \%$ of its habitants lives there with 70658 habitants (around 33018 habitants. $\mathrm{km}^{-2}$ ). At the north it's limited by the see, at the east by the Havana bay while at the south and west by the rest of the municipality's territory.

Dust samples were collected at 33 stations homogeneously distributed through the studied area (Figure 1). Dust samples (around 100g) were collected by gently sweeping an area of about $16 \mathrm{~m}^{2}$ in selected stations homogenously distributed trying to be close to parks, high traffic avenues, schools, constructions, residential areas and shops. All samples were transferred to a clean, self-sealed polyethylene bag. In the laboratory, large rock, metallic and plastic pieces and organic debris were removed before sieving at a fraction smaller than 63 $\mu \mathrm{m}$. Then the powder samples were dried at $35^{\circ} \mathrm{C}$ until obtaining a constant weight. 


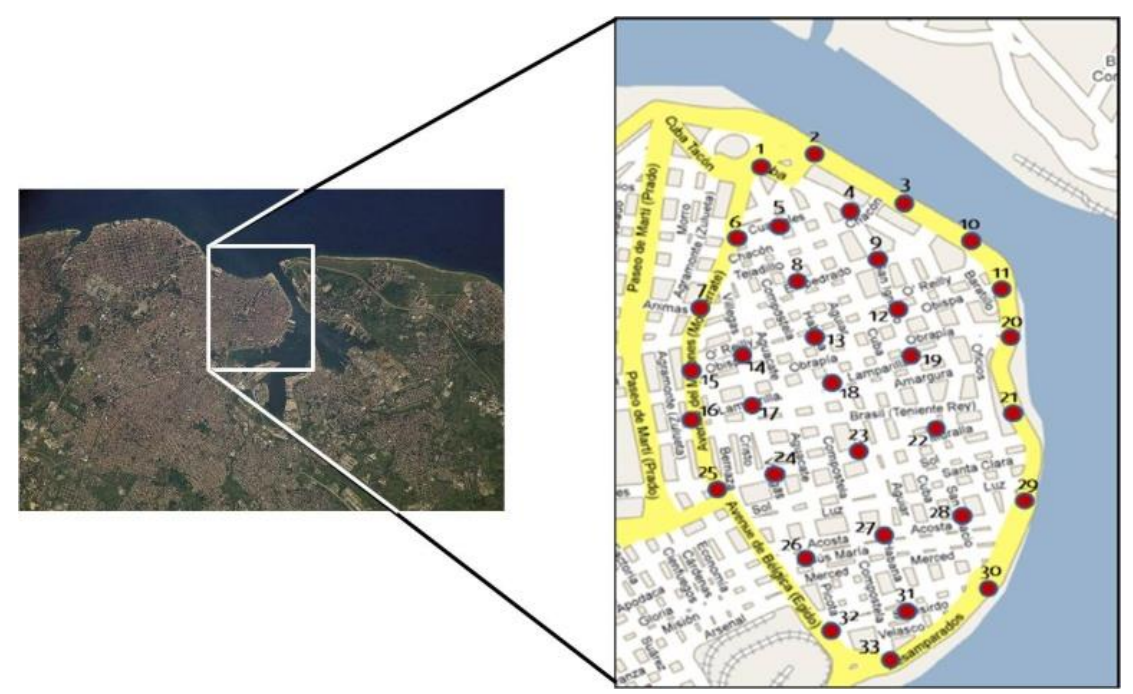

Figure 1. Location of the sampling stations in Historical Center of Havana

The heavy metal concentrations were estimated by X-Ray Fluorescence Analysis (XRF) using the Certified Reference Materials (CRM) IAEA-Soil-7, MAG-1 "Marine sediment", IAEA SL-1 "Lake sediment", IAEA Soil-5, IAEA-356 "Polluted marine sediment", BCSS-1 "Marine sediment", BCR-2 "Basalt Columbia River" and SGR-1"Green River Shale". All samples and CRM were mixed with cellulose (analytical quality) in proportion 4:1 and pressed at 15 tons into the pellets of $25 \mathrm{~mm}$ diameter and 4-5 mm height. All pellets were measured using Canberra $\mathrm{Si}(\mathrm{Li})$ detector $(150 \mathrm{eV}$ energy resolution at $5.9 \mathrm{keV}$, Be window thickness $=12.0$ $\mu \mathrm{m})$ coupled to MCA. A ${ }^{238} \mathrm{Pu}(1.1 \mathrm{GBq})$ excitation source with ring geometry was used. All spectra were processed with WinAxil code (WinAxil, 2005).

The accuracy of the quantification was verified using the McFarrel criterion (Quevauviller and Marrier 1995) in which an SR parameter is defined as $=\frac{\left|C_{\exp }-C_{w}\right|+2 \sigma}{C_{w}} * 100 \%$, where, $C_{\exp }$ is the experimentally determined concentration, $C_{w}$ is the concentration reported for the measured CRM and $\sigma$ is the standard deviation of $C_{\text {exp }}$. Based on this criterion, the similarity between the reported value and the data analytical concentration, obtained by a particular method, is divided into three categories: if SR $\leq 25 \%$, the method is considered excellent for analysis; $25 \% \leq \mathrm{SR} \leq 50 \%$, it is considered acceptable and for SR values $>50 \%$, the method it is considered unacceptable for quantification. The XRF analysis of CRM IES-951 (Table 1), shows an excellent quality with $\mathrm{SR}<25 \%$ for all the analyzed metals and the obtained results shows a very good correlation between certified and measured values.

Table 1. Analysis of the CRM IES-951 using ED-XRF (Concentration $\pm \mathrm{SD}, \mathrm{mg} \cdot \mathrm{kg}^{-1}$, except indicated), SR values and Detection Limits (Díaz Rizo et al. 2011).

\begin{tabular}{|l|l|l|l|l|}
\hline Element & Calculated Concentration & Reported Concentration & $\mathrm{SR}(\%)$ & $\mathrm{L}_{\mathrm{D}}\left(\mathrm{mg} \mathrm{Kg}^{-1}\right)$ \\
\hline $\mathrm{Fe}(\%)$ & $3.13 \pm 0.11$ & $2.97 \pm 0.09$ & 12 & 9 \\
\hline $\mathrm{Co}$ & $12.5 \pm 1.42$ & $12.5 \pm 1.44$ & 23 & 6 \\
\hline $\mathrm{Ni}$ & $37.3 \pm 3.2$ & $37.9 \pm 2.82$ & 19 & 7 \\
\hline $\mathrm{Cu}$ & $22.7 \pm 0.86$ & $20.1 \pm 2.31$ & 22 & 6 \\
\hline $\mathrm{Zn}$ & $102.5 \pm 5.5$ & $96.1 \pm 5.8$ & 18 & 5 \\
\hline $\mathrm{Pb}$ & $33.3 \pm 2.55$ & $36.9 \pm 4.01$ & 24 & 4 \\
\hline
\end{tabular}

Spatial distribution maps of heavy metal concentration of interest present in the urban dusts of the $\mathrm{HCH}$, were built by the Surfer graphing and calculation software (Surfer,version 10.1.561,1993-2011) using the Kriging algorithm.

98 The degree of contamination present in dust samples was evaluated using the dimensionless variable 99 
where $C_{n}$ is the concentration of the potentially enriched metal and $C_{r e f}$ is the reference metal concentration. An $E F>1$ means the existence of a non-natural contribution to the concentration determined of an element. The degree of enrichment depending on the $E F$ value according to Sutherland (2000) is: $E F<2$, minimal enrichment; $2<E F<5$, moderate enrichment; $5<E F<20$, significant enrichment; $20<E F<40$, very high enrichment; and $E F>40$, extremely high enrichment.

Generally, $E F$ less than 2 it is not considered significant, since a small value of $E F$ may be due to fluctuations relative to the used natural background, or for the accuracy and precision of the analytical technique used (Sinem Atgin et al. 2000). In this research, iron was used as reference metal for the normalization as it is hardly influenced by anthropogenic sources due to the high natural levels of this element (Villares et al. 2003).

Additionally, the dust contamination level was evaluated using the Integral Pollution Index (IPI) (Cheng et al. 2005; Sun et al. 2010), which is defined as the average value of all the values of the Pollution indexes for the metals considered $I P I=\frac{1}{N} \sum_{n=1}^{N} P I_{n}$, where $\mathrm{N}$ is the number of metals considered in the study. The Pollution Index (PI) is defined as the ratio of the concentration of the heavy metal in the studied dust and the geometric mean of the metal concentration of soil taken as background $P I_{n}=C_{n} / B_{n}$, where $C$ is the concentration of the metal to be determined and $B$ the concentration in the soil taken as background (Cheng et al. 2005). The classifications of pollution for these indexes according to Hakanson (1980) are: $(P I<1 ; I P I \leq 1.0)$ Slightly contaminated; $(1 \leq P I<3 ; 1<I P I \leq 2)$ Moderately contaminated; $(3 \leq P I<6 ; 2<I P I \leq 5)$ Considerably contaminated; $(6 \leq P I ; 5<I P I)$ Highly contaminated.

In both cases, $E F$ and $P I$ indexes, the heavy metal content reported for non-urbanized soils of Havana city (Díaz Rizo, et al. 2011) was used as background metal content.

The calculation of the health risk of exposure to heavy metals is based on the studies carried out by the United States Environmental Protection Agency (USEPA 1986; USEPA 1989; USEPA 2002). Health risks can be divided into two categories: risk of acquiring a carcinogenic disease and risks of acquiring a non-carcinogenic disease. For the non- carcinogenic it is used the Average Daily exposure Doses $\left(A D D, \mathrm{mg} \cdot \mathrm{kg}^{-1}\right.$. $\left.\mathrm{day}^{-1}\right)$ received estimated through the three ways of incorporation to which people are exposed to heavy metals from urban dust (inhalation, ingestion and dermal contact).

$$
\begin{gathered}
A D D_{\text {ing }}=C \times \frac{R_{\text {ing }} \times F E \times E D}{B W \times T} ; A D D_{\text {der }}=C \times \frac{S A \times S L \times A B S \times F E \times E D}{B W \times T} ; A D D_{\text {inh }}=C \times \frac{R_{\text {inh }} \times F E \times E D}{P E F \times B W \times T} \text { and } L A D D_{\text {inh }}= \\
\frac{C \times F E}{P E F \times T}\left(\left(\frac{R_{\text {inh }} \times E D}{B W}\right)_{\text {child }}+\left(\frac{R_{\text {inh }} \times E D}{B W}\right)_{\text {adult }}\right)
\end{gathered}
$$

where, $C\left(\mathrm{mg} \mathrm{kg}^{-1}\right)$ is the concentration of the metal in the studied dust; $R_{\text {ing }}$ is the ingestion rate: $200 \mathrm{mg} / \mathrm{day}$ for adults and $100 \mathrm{mg} /$ day for children (USEPA 2002); $R_{\text {inh }}$ is the inhalation rate: $20 \mathrm{~m}^{3} / \mathrm{day}$ for adults and 7.6 $\mathrm{m}^{3} /$ day for children (Zheng et al. 2010; USEPA 2002); $E D$ is the exposure duration: 24 years for adults and 6 years for children; $P E F$ is the particle emission factor, that is, the relationship between the concentration of a pollutant in the dust with the concentration of particles of these pollutants that are suspended in the air we breathe: $1.36 \times 10^{9} \mathrm{~m}^{3} \mathrm{~kg}^{-1} ; S A$ it is the exposed skin area: $5700 \mathrm{~cm}^{2}$ for adults and $2800 \mathrm{~cm}^{2}$ for children; $S L$ is the skin adhesion factor: $0.7 \mathrm{mg} . \mathrm{cm}^{-2}$.day ${ }^{-1}$ for adults and $0.2 \mathrm{mg} . \mathrm{cm}^{-2}$.day ${ }^{-1}$ for children; $A B S$ is the dermal absorption factor, is a dimensionless value and is 0.001 for all items considered; $B W$ is the average body weight: $70 \mathrm{~kg}$ for adults and $15 \mathrm{~kg}$ for children; $F E$ is the exposure frequency: 350 days.year ${ }^{-1}$ and $T$, the average time, is the period of time from which the dose is averaged: $E D^{*} 365$ days for risks associated with non-carcinogenic diseases and 70*365 days for risks associated with carcinogenic diseases (USEPA 2002). LADD inh is the Lifetime Average Daily Dose used for cancer risk calculations.

The hazard quotient $(H Q)$, which is defined as $H Q=A D D / R f D$ of a chemical element, it is used to calculate the non-carcinogenic risk. To determine the effect of the three forms of exposure for each metal, the Hazard Index (HI) (USEPA 1986) is calculated as $H I=H Q_{i n g}+H Q_{i n h}+H Q_{d e r}$. If $H I<1$, then there will be no risk of acquiring a non-carcinogenic disease, if $H I>1$, then there is a certain probability of acquiring a noncarcinogenic disease, which tends to increase with the $H I$ value. The used $R f D$ values for each metal are present in Table 2. 
Table 2. $R f D\left(m g \cdot \mathrm{kg}^{-1} \cdot \mathrm{d}^{-1}\right)$ values for non-carcinogenic metals and Slope factors $\left(\left(\mathrm{mg} \cdot \mathrm{kg}^{-1} \cdot \mathrm{d}^{-1}\right)^{-1}\right)$ for carcinogenic metals (Zhang et al. 2018)

\begin{tabular}{|l|l|l|l|l|l|}
\hline & $\mathrm{Co}$ & $\mathrm{Ni}$ & $\mathrm{Cu}$ & $\mathrm{Zn}$ & $\mathrm{Pb}$ \\
\hline$R f D_{\text {ing }}$ & 0.02 & 0.02 & 0.04 & 0.3 & 0.0035 \\
\hline$R f D_{\text {inh }}$ & 0.0000571 & 0.0206 & 0.012 & 0.3 & 0.00352 \\
\hline$R f D_{\text {der }}$ & 0.016 & 0.0008 & 0.04 & 0.06 & 0.000525 \\
\hline$S F_{\text {inh }}$ & 9.8 & 0.84 & - & - & - \\
\hline
\end{tabular}

The $\mathrm{Ni}$ and Co have the potential to pose Carcinogenic Risk $(C R)$ through respiratory exposure. This is the probability that an individual develops some type of cancer during the exposure time to a carcinogenic risk. It is calculated as $C R_{\text {metal }}=L A D D_{\text {inh }} \times S F_{\text {inh }}$ where $S F$ is the slope factor wish values are also presented in Table 2. An acceptable or tolerable value of $C R=\sum C R_{\text {metal }}$ is in the range between $\left(10^{-6}-10^{-4}\right)$.

\section{Results and Discussion}

The means of the metal $(\mathrm{Fe}, \mathrm{Co}, \mathrm{Ni}, \mathrm{Cu}, \mathrm{Zn}$ and $\mathrm{Pb}$ ) concentrations determined by $\mathrm{X}$-ray fluorescence analysis of urban road dusts from the $\mathrm{HCH}$ in the different stations are shown in Table 3, as well as the standard deviations, medians, maximums, minimums, background values and the reported values from the calculation of concentration of heavy metals in the upper crust (Hans 1995).

Table 3. Statistical results of the concentration (in mg. $\mathrm{kg}^{-1}$, except the indicated) of analyzed metals, background used and upper crust. ( ${ }^{a}$ (Díaz Rizo et al. 2011) ${ }^{\text {b }}$ (Hans 1995))

\begin{tabular}{|l|l|l|l|l|l|l|}
\hline & $\mathrm{Fe}(\%)$ & $\mathrm{Co}$ & $\mathrm{Ni}$ & $\mathrm{Cu}$ & $\mathrm{Zn}$ & $\mathrm{Pb}$ \\
\hline Average & 1.2 & 7.0 & 60.6 & 73.6 & 548.7 & 60.8 \\
\hline SD & 0.3 & 1.1 & 218.5 & 262.8 & 578.3 & 70.5 \\
\hline Minimum & 0.7 & 6.0 & 11.0 & 16.0 & 124.0 & 22.0 \\
\hline Maximum & 2.2 & 10.4 & 1276.0 & 1535.0 & 3012.0 & 422.0 \\
\hline Median & 1.2 & 6.6 & 20.0 & 24.0 & 358.0 & 39.0 \\
\hline Average/Median & 1.0 & 1.1 & 3.0 & 3.1 & 1.5 & 1.6 \\
\hline Background $^{\mathrm{a}}$ & 4.7 & 14.8 & 58 & 83 & 151 & 28 \\
\hline Upper Crust $^{\mathrm{b}}$ & 4.32 & 24 & 56 & 25 & 65 & 14.8 \\
\hline
\end{tabular}

Standard deviations show large values respect de mean values due to outliers at some stations. Station 24 and 23 show the highest values (3012 and $1750 \mathrm{mg} \cdot \mathrm{kg}^{-1}$ respectively) for $\mathrm{Zn}$, this could be because between these stations, it is the largest parking lot in the municipality where there was a workshop where they used to do sheet metal work (using zinc plates), and a punch bowl ( $\mathrm{ZnO}$ is a rubber compound). It used to be another punch bowl at the same street of station 24 . There are also some constructions around where new buildings were made. $\mathrm{Zn}$ is used for roofing and as a component of cement and paints. Stations $19\left(1170 \mathrm{mg} \cdot \mathrm{kg}^{-1}\right)$ and $6\left(1461 \mathrm{mg} \cdot \mathrm{kg}^{-}\right.$ ${ }^{1}$ ) have also outliers for $\mathrm{Zn}$, presumably due to the large construction sites next to them. In the case of station 6 has also the highest values for $\mathrm{Ni}$ and $\mathrm{Cu}$ because this construction is a museum in capital restauration where big pieces of bronze (containing $\mathrm{Cu}$ ), stainless steel (containing $\mathrm{Ni}$ ) and galvanized steel pipes (containing $\mathrm{Ni}$ and $\mathrm{Zn}$ ) received maintenance.

The highest $\mathrm{Pb}$-content ( $422 \mathrm{mg} \cdot \mathrm{kg}^{-1}$ ) was found at station 2. At this place there is small seaport for fisher boats that use oil as fuel and it is the main exit of all the vehicles that cross the Havana bay tunnel. The average / median ratios for $\mathrm{Fe}$ and $\mathrm{Co}$ are close to 1 , so there are not outliers and it can be stated that its origins must be predominantly natural. Figure 2 shows the spatial distribution for the determined heavy metals. 

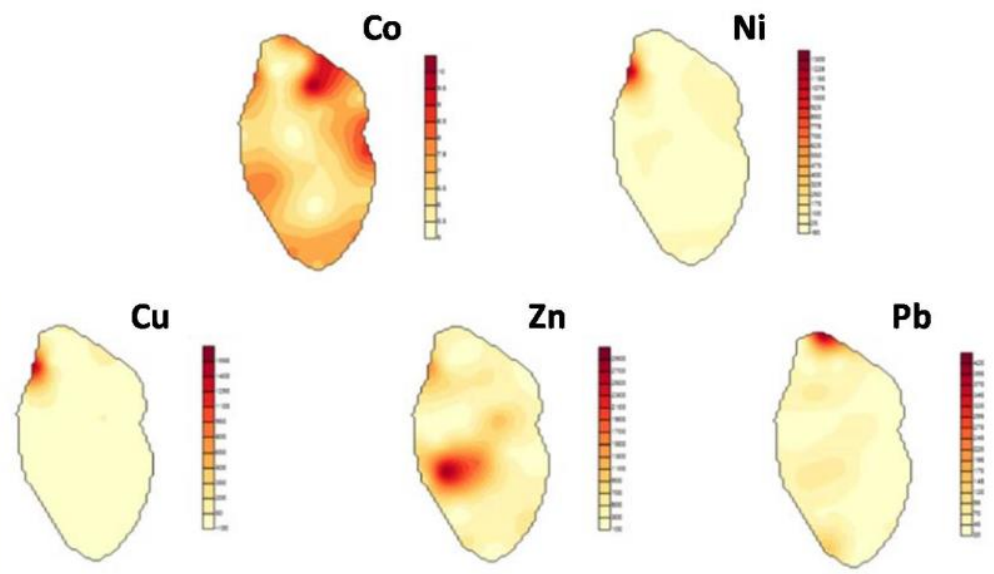

173

174

175

176

177

178

179

180

181

182

183

184

185

186

187

188

189

190

191

Figure 2. Spatial distribution of the determined heavy metals contents analyzed in the $\mathrm{HCH}\left(\mathrm{mg} \cdot \mathrm{kg}^{-1}\right)$ The average concentration values show a decrease in the form $\mathrm{Zn}>\mathrm{Cu}>\mathrm{Pb}>\mathrm{Ni}>\mathrm{Co}$. The determined average/background contents show 3.6 and 2.2 for $\mathrm{Zn}$ and $\mathrm{Pb}$, respectively. Referent to the earth's upper crust, $\mathrm{Zn}$ and $\mathrm{Pb}$ contents show a remarkable excess, while $\mathrm{Ni}$ and $\mathrm{Cu}$ are closer to the corresponding reference values (Hans 1995). The Pearson correlation of the metal contents determined in urban road dusts of the HCH (Table 4) shows a high Fe-Co correlation indicating some probability of having a common origin. The other metals show a lower correlation.

Table 4. Correlation between determined metals.

\begin{tabular}{|l|l|l|l|l|l|l|}
\hline & $\mathrm{Fe}$ & $\mathrm{Co}$ & $\mathrm{Ni}$ & $\mathrm{Cu}$ & $\mathrm{Zn}$ & $\mathrm{Pb}$ \\
\hline $\mathrm{Fe}$ & 1 & & & & & \\
\hline $\mathrm{Co}$ & $0.74^{* *}$ & 1 & & & & \\
\hline $\mathrm{Ni}$ & $0.23^{* *}$ & $0.19^{* *}$ & 1 & & & \\
\hline $\mathrm{Cu}$ & $0.23^{* *}$ & $0.33^{* *}$ & 0.06 & 1 & & \\
\hline $\mathrm{Zn}$ & 0.06 & 0.03 & -0.03 & -0.02 & 1 & \\
\hline $\mathrm{Pb}$ & $0.25^{* *}$ & 0.07 & 0.01 & $0.14^{*}$ & $0.25^{* *}$ & 1 \\
\hline \multicolumn{6}{|l|}{} \\
\hline \multicolumn{7}{|l|}{} \\
\hline
\end{tabular}

Table 5 shows the comparison between the metal content determined in the urban dusts from the HCH with contents reported for other Cuban cities, as well as contents reported for historical centers worldwide. $\mathrm{Zn}$ concentration levels are most notable for above the other places, although for the rest of the metals these values are generally in the order of the reported concentrations. On the other hand, when comparing them with the soil quality reference values (QRV) recommended for Cuba (Alfaro et al.2015) it is observed that the concentrations of $\mathrm{Co}, \mathrm{Ni}$ and $\mathrm{Cu}$ are lower, $\mathrm{Pb}$ content it is slightly higher, while $\mathrm{Zn}$ content significantly exceeds the $\mathrm{Zn} \mathrm{QRV}$ value at 6.4 fold.

Table 5. Average metal concentrations (in $\mathrm{mg} \cdot \mathrm{kg}^{-1}$, except the indicated) in the $\mathrm{HCH}$ road dust and its comparison with similar studies in other Cuban and worldwide cities. ('Present work, ${ }^{\mathrm{b}}$ (Díaz Rizo et al. 2015), ${ }^{\mathrm{c}}$ (Díaz Rizo et al. 2019), ${ }^{\mathrm{d}}\left(\right.$ Wei et al. 2015), ${ }^{\mathrm{e}}$ (Bretzel et al.2014), ${ }^{\mathrm{f}}$ (Elik 2003), ${ }^{\mathrm{g}}($ Christoforidis \& Stamatis, 2009), ${ }^{\mathrm{h}}$ (Divrikli et al. 2003), ${ }^{\mathrm{i}}$ (Bourliva et al.2016), ${ }^{\mathrm{j}}$ (Alfaro et al. 2015))

\begin{tabular}{|c|c|c|c|c|c|}
\hline City & Co & $\mathrm{Ni}$ & $\mathrm{Cu}$ & $\mathrm{Zn}$ & $\mathrm{Pb}$ \\
\hline $\mathrm{HCH}, \mathrm{Cuba}^{\mathrm{a}}$ & $7.0 \pm 1.1$ & $60.6 \pm 218.5$ & $73.6 \pm 262.8$ & $548.7 \pm 578.3$ & $60.8 \pm 70.5$ \\
\hline Camaguey, Cuba ${ }^{b}$ & $15 \pm 4$ & $66 \pm 36$ & $36 \pm 12$ & $222 \pm 84$ & $63 \pm 13$ \\
\hline Havana, Cuba ${ }^{c}$ & NR & $68 \pm 131$ & $65 \pm 152$ & $369 \pm 375$ & $88 \pm 114$ \\
\hline Beijing, China ${ }^{d}$ & NR & $26 \pm 6$ & 86 & 272 & 235 \\
\hline Pisa, Italy ${ }^{\mathrm{e}}$ & NR & $91.9 \pm 1.3$ & $107 \pm 2$ & $327 \pm 1$ & $207 \pm 4$ \\
\hline Sivas, Turkey ${ }^{f}$ & NR & $81 \pm 4$ & $107 \pm 6$ & $284 \pm 12$ & $325 \pm 10$ \\
\hline Kavala, Greece ${ }^{g}$ & NR & $68 \pm 48$ & $172 \pm 88$ & $355 \pm 115$ & $387 \pm 245$ \\
\hline
\end{tabular}




\begin{tabular}{|l|l|l|l|l|l|}
\hline Yozgat, Turkey $^{\mathrm{h}}$ & $24 \pm 4$ & $51 \pm 9$ & $38 \pm 3$ & $\mathrm{NR}$ & $69 \pm 13$ \\
\hline Thessaloniki, Greece $^{\mathrm{i}}$ & $\mathrm{NR}$ & $89.4 \pm 44.6$ & $662 \pm 348$ & $453 \pm 224$ & $209 \pm 91$ \\
\hline $\mathrm{QRV}^{\mathrm{j}}$ & 25 & 170 & 83 & 86 & 50 \\
\hline
\end{tabular}

The $E F$ values for the analyzed metals are presented in Figure 3. The average enrichments resulted: $E F_{\mathrm{Co}}=1.9$; $E F_{\mathrm{Ni}}=3.5 ; E F_{\mathrm{Cu}}=3.0 ; E F_{\mathrm{Zn}}=13.7$ and $E F_{\mathrm{Pb}}=8.5$. According to the Sutherland (2000), Co presents a minor enrichment. $\mathrm{Ni}$ and $\mathrm{Cu}$ are found in the moderate enrichment level with an outlier at station 6 that move the average to this region. $\mathrm{Pb}$ and $\mathrm{Zn}$ have significant enrichments. The highest value of $E F_{Z n}=61.6$ was determined at station 24 as expected due to his high $\mathrm{Zn}$ concentration at this station close to the former car bodyshop, punchbowls and constructions. In Cuba, leaded fuels are not used since the end of the 90s (Montero et al. 2017). However, the use of $\mathrm{Pb}$-doped fuels for many years, must be the reason of the significant $E F$ level for $\mathrm{Pb}$ in the city since lead exhausts could have been accumulated in parks, walls and streets for years.

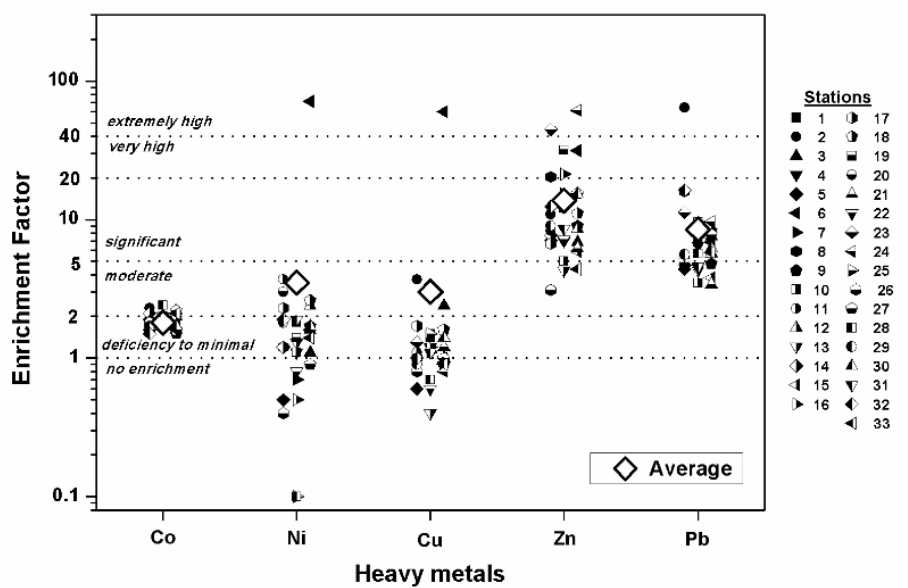

Figure 3. Enrichment Factor values for the metals determined in the urban dust of the $\mathrm{HCH}$.

The average value, over all the stations, of the $P I$ and the $I P I$ is presented in Figure 4 . The $P I_{C o}=0.5$ and $P I_{C u}$ $=0.9$ indicate a low contamination, $P I_{N i}=1$ and $P I_{P b}=2.2$ are at a moderate level and $P I_{Z n}=3.6$ presents considerable contamination. However, there are some stations with high pollution, as in the case of station 6 $\left(P I_{N i}=22, P I_{C u}=18.5\right), 23\left(P I_{Z n}=11.6\right), 24\left(P I_{Z n}=19.9\right)$ and 2 with $P I_{P b}=15.5$. According to the $I P I$, all the stations show low to moderate contamination except stations $2,19,23$ and 24 with considerably contamination and station 6 with extremely high contamination.

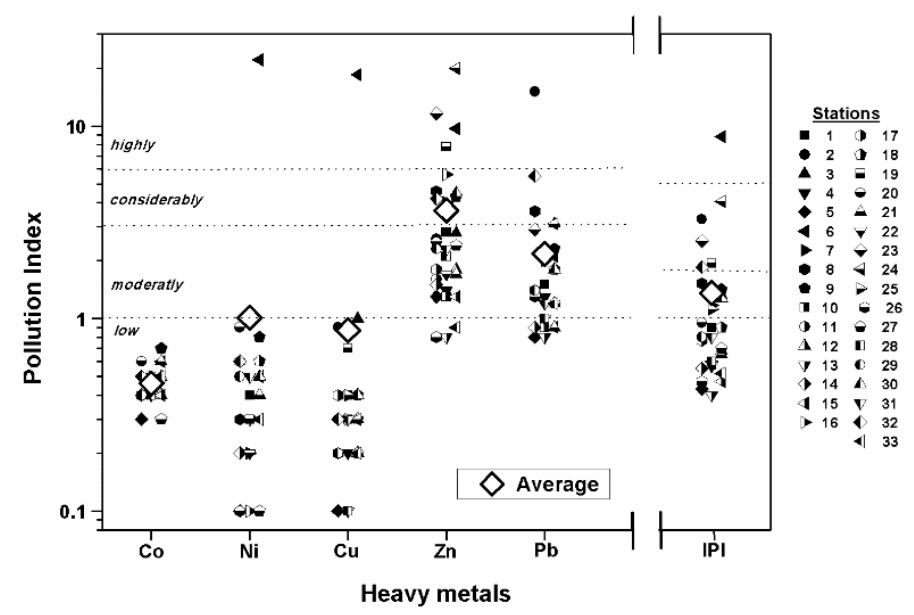


Figure 4. Pollution Index values for the metals determined in the urban dust of the $\mathrm{HCH}$ and the Integrated Pollution Index. Independently of the mentioned high metal enrichments, the calculated metal Hazard Indexes for children and adults for all studied stations are less than unity (Figure 5), indicating no risk for non-carcinogenic diseases. Additionally, the probability to develop carcinogenic disease for each carcinogenic metal as well as the total are under tolerable range, indicating no risk of getting a carcinogenic disease. These values indicate that the heavy metals analyzed do not represent a health problem.

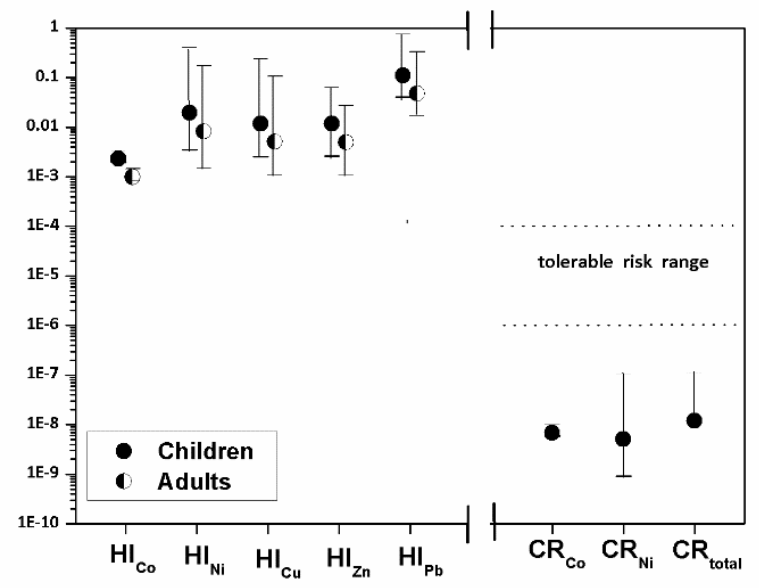

Figure 5. Hazard Index averages and ranges of values for children and adults and the Carcinogenic Risk Conclusions and Recommendations

Heavy metal content in urban road dust from the historical center of Havana show the behavior $\mathrm{Zn}>\mathrm{Cu}>\mathrm{Pb}>$ $\mathrm{Ni}>\mathrm{Co}$, with $\mathrm{Zn}$ and $\mathrm{Pb}$ averages higher than quality reference values recommended for Cuba.

The $E F$ and $P I$ show the same behavior $(\mathrm{Zn}>\mathrm{Pb}>\mathrm{Ni}>\mathrm{Cu}>\mathrm{Co})$ with almost all the stations in the range of moderate or less enrichment and pollution for $\mathrm{Co}, \mathrm{Ni}$ and $\mathrm{Cu}$. $\mathrm{Pb}$ has a significant enrichment but only three stations show considerably or more pollution index. Zn shows a significant or higher enrichment in almost all the stations and in correspondence the pollution index goes from moderately to highly pollution.

Health risk assessment shows that $H I$ and $C R$ are in safe ranges. That confirm that the $\mathrm{HCH}$ city is a safe place for visitors and habitants independently the great reconstruction movement performed in the last years.

However, taking into account that the reconstruction movement will continue in the next years, the check of the heavy metal content will be continued as well as the health risks assessments in order to guaranteed safe levels.

\section{References}

Alfaro M. R., Montero A., Ugarte O. M. et al. (2015). Background concentrations and reference values for heavy metals in soils of Cuba; Environ Monit Assess; 187: 4198. https://doi.org/10.1007/s10661-014-4198-3

Bourliva A., Christophoridis C. E., Papadopoulos A., Mitsika E. (2016). Characterization, heavy metal content and health risk assessment of urban road dusts from the historic center of the city of Thessaloniki, Environ Geochem Health. https://doi.org/10.1007/s10653-016 -9836-y

Bretzel F., Benvenuti S., Pistelli L. (2014). Metal contamination in urban street sediment in Pisa (Italy) can affect the production of antioxidant metabolites in Taraxacum officinale Weber. Environ Sci Pollut Res, 21: 2325-2333. https://doi.org/10.1007/s11356-019-2147-2

Charlesworth, S., De Miguel, E., Ordóñez, A., (2011). A review of the distribution of particulate trace elements in urban terrestrial environments and its application to considerations of risk. Environ. Geochem. Health 33 (2): 103-123.

Cheng T. B., Zheng Y.M., Lei M., Huang Z.C., Wu H.T., Chen H., Fan K.K., Yu K., Wu X., Tian Q.Z. (2005). Assessment of heavy metal pollution in surface soils of urban parks in Beijing, China. Chemosphere 60: 542551. 
Christoforidis A., Stamatis N. (2009). Heavy metal contamination in street dust and roadside soil along the major national road in Kavala's region, Greece. Geoderma 151: 257-263

Das P., Samantaray S. y Rout G. R. (1997). Studies on cadmium toxicity in plants: a review. Environ. Pollut. 98: 29-36.

Díaz Rizo O., Echeverría F., Arado J. O. y Hernández M. (2011). Assessment of heavy metal pollution in urban soils of Havana city, Cuba. Bulletin of Environmental Contamination and Toxicology, 87(4): 414- 419. https://doi.org/10.1007/s00128-011-0378-9

Díaz Rizo O., Rivero O., D’Alessandro K., García C. (2015). Spatial distribution and contamination assessment of heavy metals in street dust from Camagüey city (Cuba) using X-ray fluorescence. Nucleus 58: 34-38.

Díaz Rizo O, Olivares Rieumont S, Gelen Rudnikas A, et al (2019) Assessment of environmental pollution in Havana City using nuclear and related techniques. Nucleus 66:58-652.

Divrikli U., Soylak M., Elci L. y Dogan M. (2003) Trace Heavy Metal Levels in Street Dust Samples from Yozgat City Center, Turkey, Journal of Trace and Microprobe Techniques, 21(2): 351-361.

Elik A. (2003) Heavy Metal Accumulation in Street Dust Samples in Sivas, Communications in Soil Science and Plant Analysis, 34:1-2, 145-156

García L. L., Poleto C. (2014). Assessment of diffuse pollution associated with metals in urban sediments using the geoaccumulation index (Igeo). J. Soils Sediments: 1-7.

Hakanson L. (1980). An ecological risk index for aquatic pollution control. A sedimentological approach, Water Res. 14: $975-1001$.

Hans K. (1995). The composition of the continental crust. Geochimica et Cosmochimica Acta, Vol. 59, No. 7: 1217-1232

Lu X., Li L., Zhao N., Shang D., Li R. (2014). Concentration, speciation and environmental risk of heavy metal in dusts collected from the different functional areas of a medium-size city in China. International Journal of Environmental Engineering- IJEE: 1.

Maltby L., Boxall A. B. A., Forrow D. M., Calow P., Betton C. I. (1995) The effects of motorway runoff on freshwater ecosystems: 2. Identifying major toxicants. Environ Toxicol Chem 14: 1093 - 1101

Montero A., Estévez J. R., Araújo C. W., Pupo I., Díaz Rizo O., Lima L., Ayllón R., Gómez J. (2017). Lead isotope ratios in lichen samples evaluated by ICP-ToF-MS to assess possible atmospheric pollution sources in Havana, Cuba. Environ Monit Assess 189: 28. https://doi.org/ 10.1007/s10661-016-5739-8

Onder S., Dursun S. (2006). Air borne heavy metal pollution of Cedrus libani (A. Rich.) in the city centre of Konya (Turkey). Atmos. Environ. 40: 1122-1133.

Ordóñez A., Álvarez R., De Miguel E., Charlesworth S. (2015). Spatial and temporal variations of trace element distribution in soils and street dust of an industrial town in NW Spain: 15 years of study. Science of the Total Environment 524-525, 93-103. http://dx.doi.org/10.1016/j.scitotenv.2015.04.024

Quevauviller Ph., Marrier E. (1995) Quality assurance and quality control for environmental monitoring, VCH, Weinheim.

Rissler J., Swietlicki E., Bengtsson A., Boman C., Pagels J., Sandstrom T., Blomberg A., Londahl J. (2012). Experimental determination of deposition of diesel exhaust particles in the human respiratory tract. J. Aerosol Sci. 48: 18-33.

Salt D. E., Prince R. C., Pickering I. J. y Raskin I. (1995). Mechanisms of cadmium mobility and accumulation in Indian mustard. Plant Physiol. 109: 1427-1433.

Sinem R., El-Agha O., Zararsiz A., Kocatas A., Parlak H., Tuncel G. (2000). Investigation of the sediment pollution in Izmir Bay: trace elements. Spectrochimica Acta, B55: 1151-1164.

Sun Y., Zhou Q., Xie X., Liu R. (2010). Spatial, sources and risk assessment of heavy metal contamination of urban soils in typical regions of Shenyang, China. J Haz Mat 174: 455-462.

Sutherland RA (2000) Bed sediment-associated trace metals in an urban stream, Oahu, Hawaii. Environ Geol 39:611-627

Sutherland R. A., Tolosa C. A. (2000) Multi-element analysis of road deposited sediment in an urban drainage basin, Honolulu, Hawaii. Environ Pollut 110:483- 495. 
USEPA (1986). Guidelines for the health risk assessment of chemical mixtures [R]. Washington, DC: US Environmental Protection Agency; [EPA/630/R-98/002].

292 USEPA (1989). Risk Assessment Guidance for Superfund. EPA/540/1-89/002. In: Human Health Evaluation Manual, vol. I. Office of Solid Waste and Emergency Response.

294 USEPA (2002). Supplemental Guidance for Developing Soil Screening Levels for Superfund Sites. U.S. 295 Environmental Protection Agency, Office of Emergency and Remedial Response, Washington.

296 Villares R., Puente X., Carballeira A. (2003). Heavy metals in sandy sediments of the Rias Baixas (NW Spain). 297 Environ Monit Assess 83: 129-144.

298 Wei B., Yang L. (2010) A review of heavy metal contaminations in urban soils, urban road dusts and agricultural soils from China. Microchem J 94:99- 107 WinAxil Code. 2005. Version 2.5. CANBERRA - MiTAC.

301 Wei X., Gao B., Wang P., Zhou H., Lu J. (2015). Pollution characteristics and health risk assessment of heavy 302 metals in street dusts from different functional areas in Beijing, China. Ecotoxicology and Environmental Safety 303 112: 186-192. http://dx.doi.org/10.1016/j.ecoenv.2014.11.005

304 Zhang Zhaoyong, Anwar Mamat, Zibibula Simayi (2018) Pollution assessment and health risks evaluation of 305 (metalloid) heavy metals in urban street dust of 58 cities in China. Environmental Science and Pollution 306 Research 26: 126-140. https://doi.org/10.1007/s11356-018-3555-0

307 Zheng N., Liu J., Wang Q., Liang Z. (2010). Heavy metals exposure of children from stairway and sidewalk 308 dust in the smelting district, northeast of China. Atmospheric Environment 44: 3239-3245. 


\section{Figures}

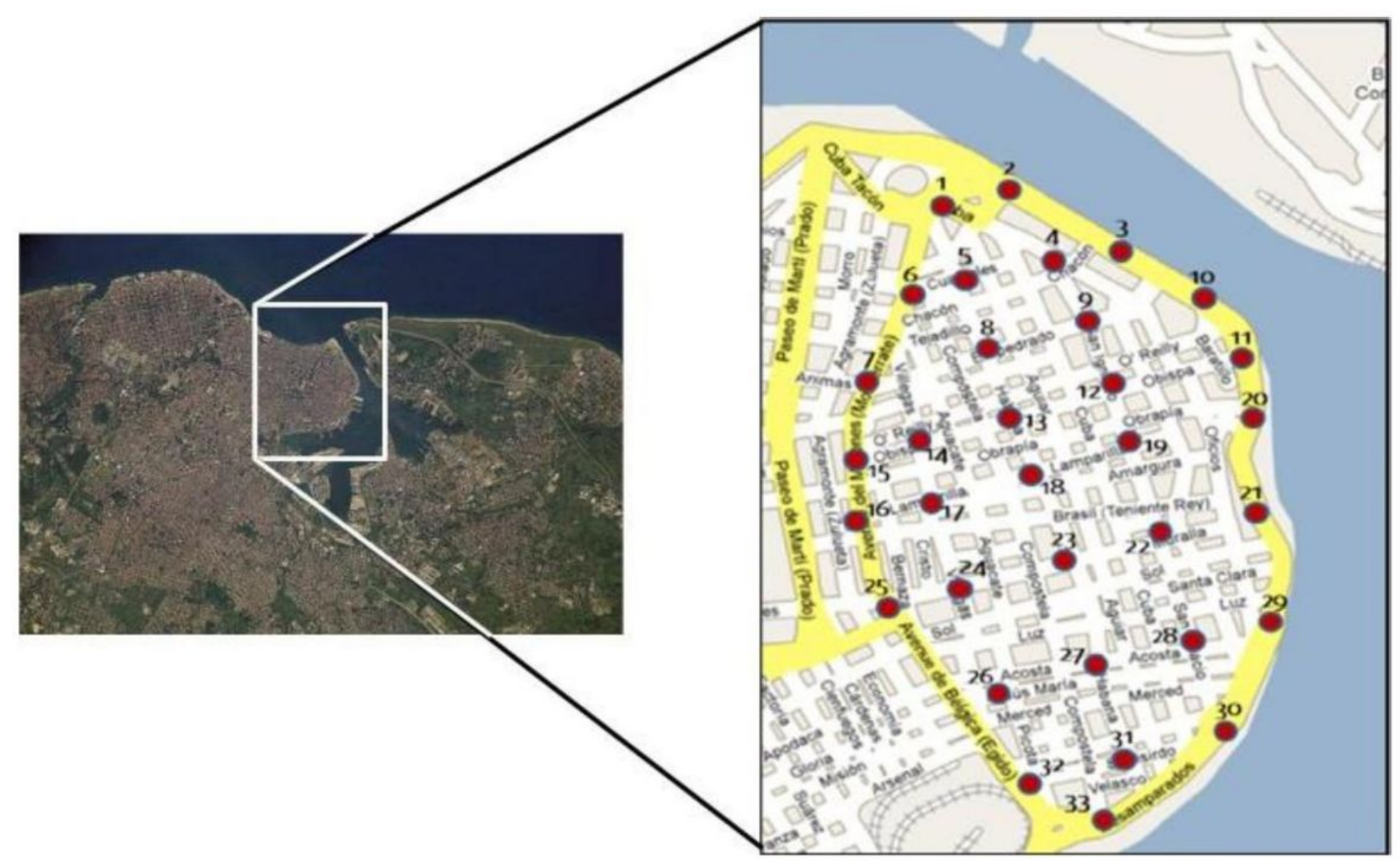

Figure 1

Location of the sampling stations in Historical Center of Havana Note: The designations employed and the presentation of the material on this map do not imply the expression of any opinion whatsoever on the part of Research Square concerning the legal status of any country, territory, city or area or of its authorities, or concerning the delimitation of its frontiers or boundaries. This map has been provided by the authors. 

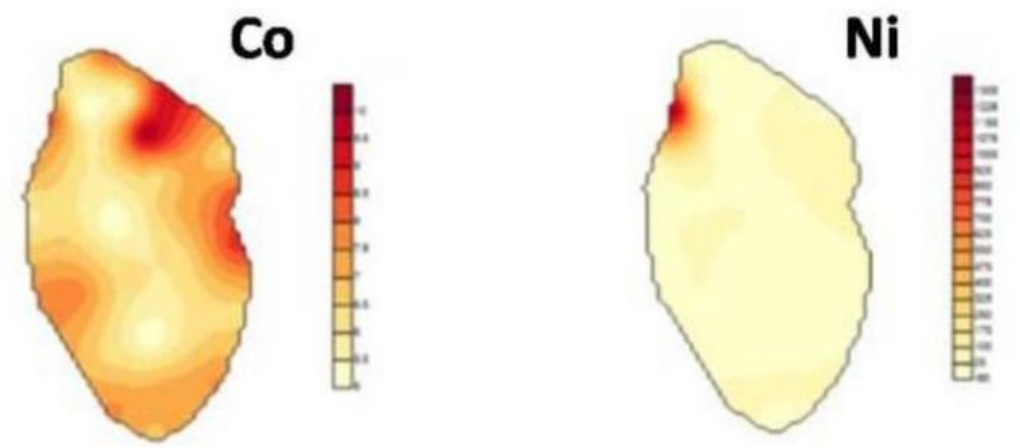

\section{$\mathrm{Cu}$}
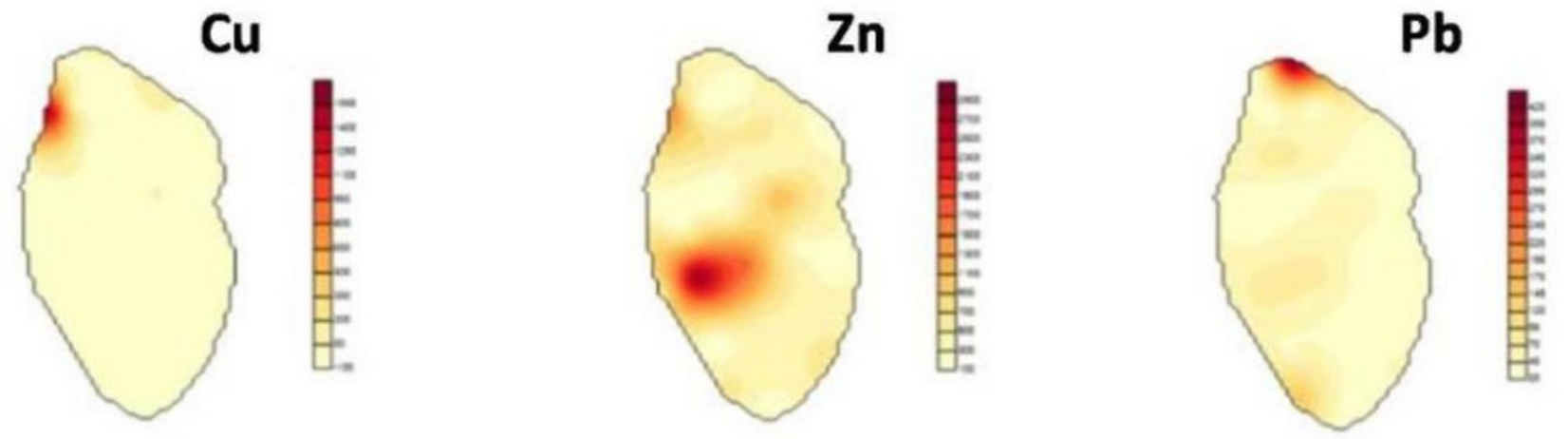

Figure 2

Spatial distribution of the determined heavy metals contents analyzed in the $\mathrm{HCH}$ (mg.kg-1)

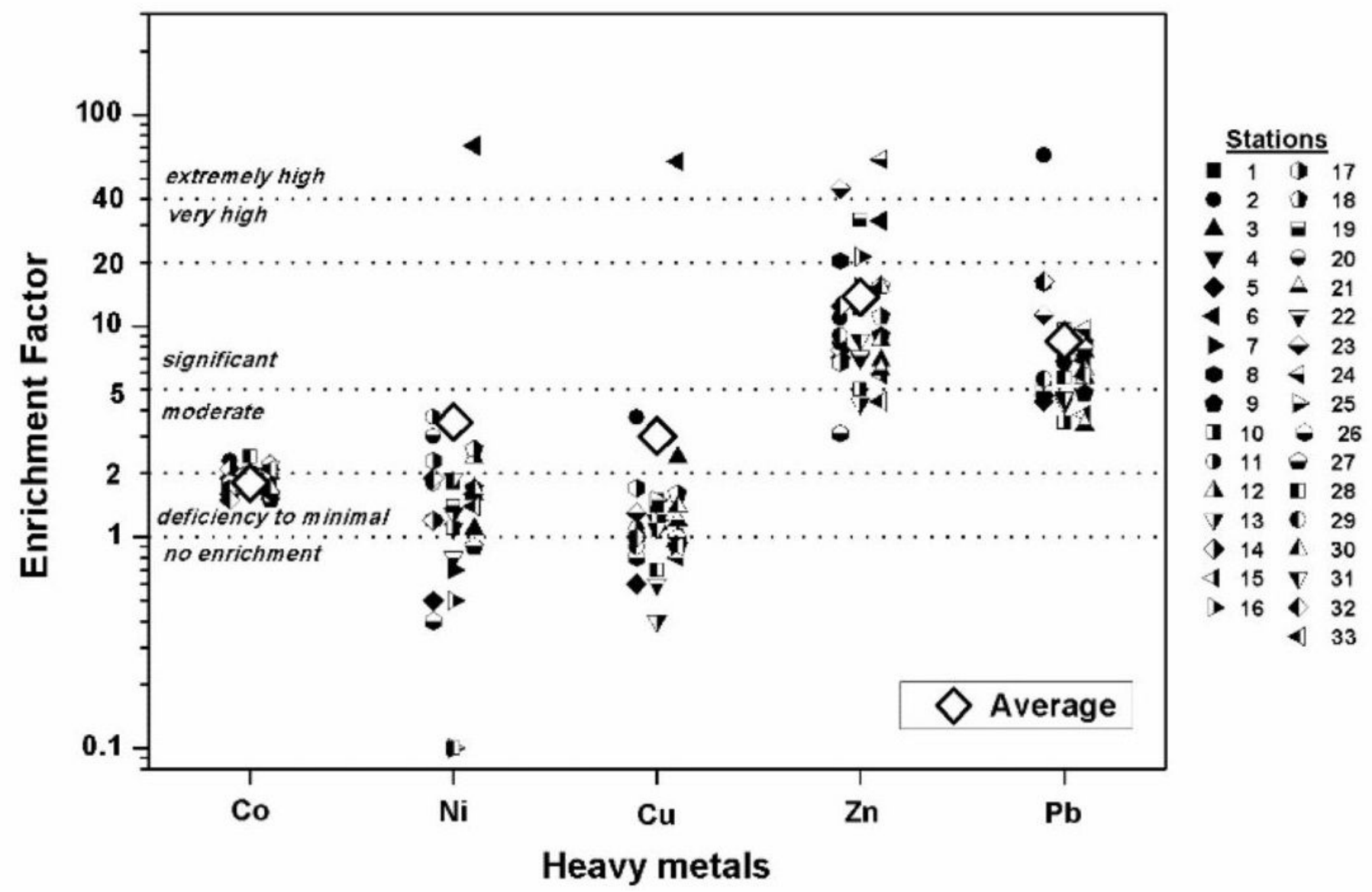


Figure 3

Enrichment Factor values for the metals determined in the urban dust of the $\mathrm{HCH}$.

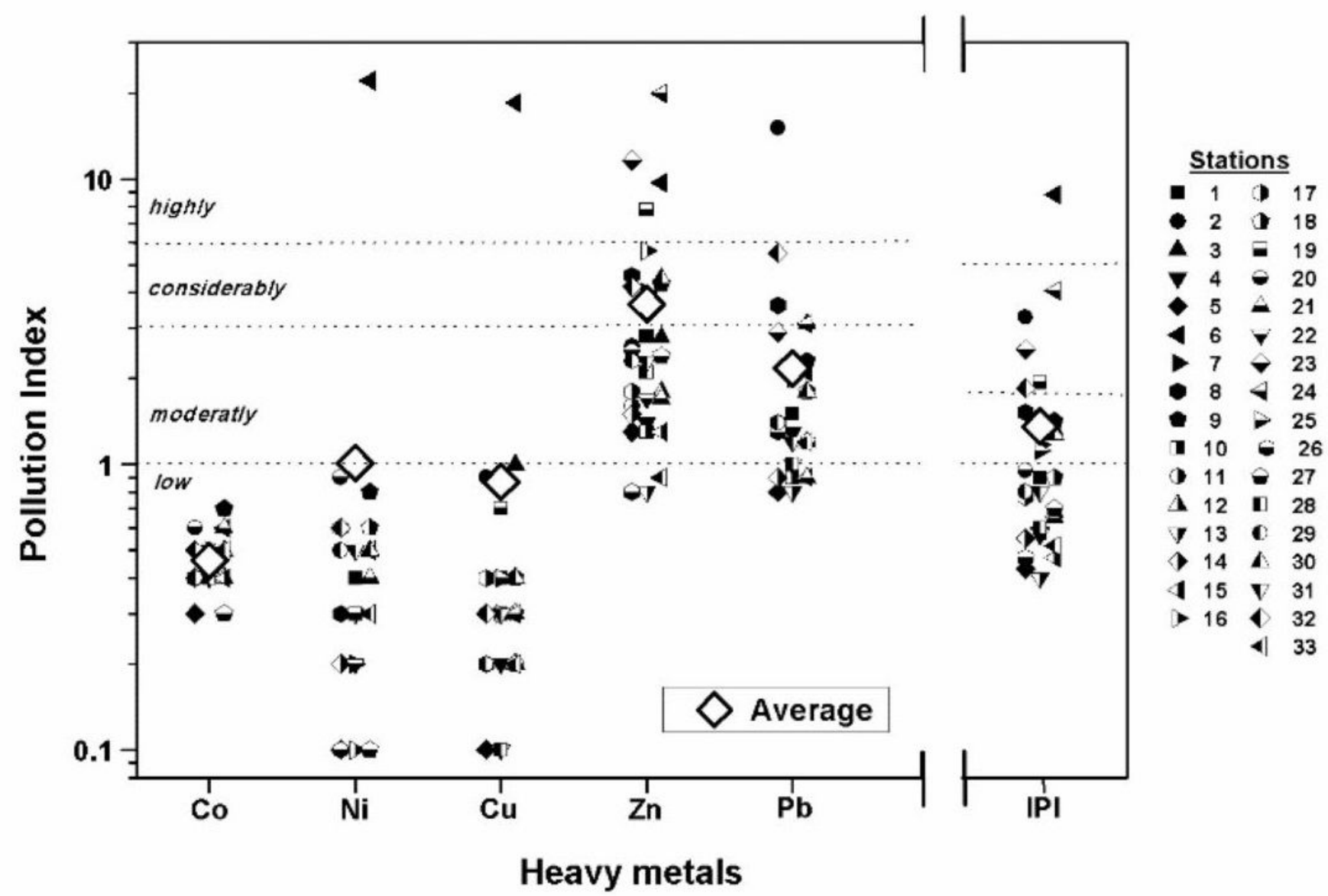

Figure 4

Pollution Index values for the metals determined in the urban dust of the $\mathrm{HCH}$ and the Integrated Pollution Index. 


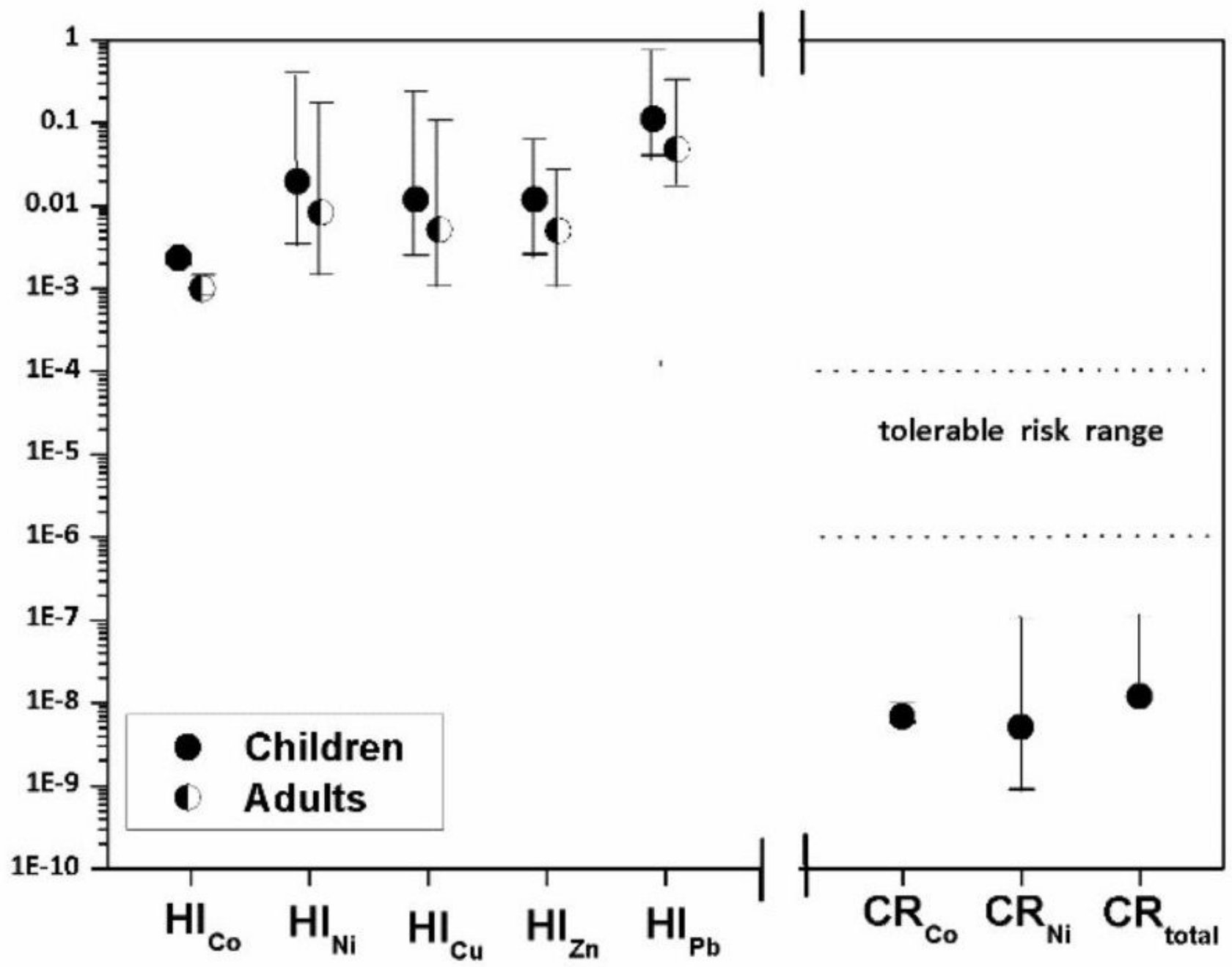

Figure 5

Hazard Index averages and ranges of values for children and adults and the Carcinogenic Risk 